\title{
A FEMINIST VINDICATION OF MARY WOLLSTONECRAFT
}

\author{
Julie A. Monroe
}

IN 1928, VIRGINIA Woolf made a statement which could well be addressed to today's feminist critics: "Towards the end of the eighteenth century a change came about which, if I were rewriting history, I should describe more fully and think of greater importance than the Crusades or the Wars of the Roses. The middle-class woman began to write." Mary Wollstonecraft is exemplary of those history-making women. Her book, A Vindication of the Rights of Woman, published in 1792, was the first truly feminist treatise acknowledged by the English public. Its continuing literary and historical importance is demonstrated by the many recent critics who have addressed Wollstonecraft's sometimes dated, sometimes surprisingly modern, themes, as well as her unusually diverse writing style. Yet curiously, contemporary feminist critics have written little in direct response to this trail-blazing work. Perhaps their neglect stems from the fact that many of Wollstonecraft's goals are accomplished and her then revolutionary ideas now seem obvious: "One thus may be tempted to sneer that Wollstonecraft's thesis has survived her stylistic experiment only because that thesis is an idea whose time has finally come." 2 If it is only in recent times that Wollstonecraft's ideas have been assimilated into commonly received notions, then there is no better time for feminist critics to further examine her philosophical treatise regarding its historical background, its often criticized style (as the above quotation suggests), and its contemporary relevance in the light of recent feminist literary theory.

Carolyn Korsmeyer suggests three theses for $A$ Vindication. First of all, Wollstonecraft argues that Reason is essential for the development of moral, virtuous character. Secondly, women lack Reason, not because they are biologically incapable of it, but because they are denied the educational opportunities that encourage the development 
of rational intellect. Finally, the common distinction between "masculine" and "feminine" virtues must be eradicated because Reason, the basis of all virtue, makes no gender distinctions. ${ }^{3}$ Though the terms of Wollstonecraft's arguments may seem dated with the emphases on Reason and morality, it seems to me that feminist issues today do not, or should not, deal any less with such terms. Certainly we do not hold Reason, with a capital $R$, in the ultimate esteem of the eighteenth- and nineteenth-century philosophers, and our concept of morality has surely become more secular, relating more to ideals of equality and individual freedom than to our relationship with a supreme deity. Nevertheless, the struggle for a less prejudiced society founded on the manifest equality of human beings must remain a modern goal.

Recent critics, in fact, do not question Wollstonecraft's basic themes but respond more specifically to the apparent ideological contradictions in A Vindication. Anca Vlasopolos finds fault with the fact that Wollstonecraft addresses her feminist treatise almost entirely to men, even divorcing herself from her own sex by referring to women as "them"; furthermore, Wollstonecraft condescends to women, berating them for behaving in exactly the ways she claims society has directed them. ${ }^{4}$ Secondly, Wollstonecraft has been criticized for failing to take her thesis beyond the limits of bourgeois ideology to its logical, radical conclusion. ${ }^{5}$ For example, despite her evocation of a "revolution in female manners," Wollstonecraft never transcends the preconceptions of the traditional female roles of wife, mother, and daughter. ${ }^{6}$ Finally, much of the recent criticism is directed at Wollstonecraft's writing style, particularly her deviations from philosophical discourse into emotional tirades and allegedly irrelevant issues. $^{7}$

To refute these invectives properly and to vindicate Mary Wollstonecraft, we must look to the most current feminist literary theory. A fundamental tenet of this discourse, formulated primarily in response to the New Criticism, asserts the necessity of examining texts within their proper contexts. The idea of "art for art's sake," particularly in the shadow of New Criticism, suggests that there is a universal point of view, an absolute standard for judging texts, outside of the contexts of history, culture, and gender. Feminist theory has demonstrated that this "universal" viewpoint is generally white; Anglo-Saxon, protestant and male. Thus, to conduct a proper feminist investigation of Wollstonecraft's treatise, we must examine it in its correct historical context.

Wollstonecraft wrote $A$ Vindication of the Rights of Woman in reponse to the French Revolution. The rise of middle-class values-liberalism, humanitarianism, and egalitarianism-all the values that inform 
present Western social and political systems, led Wollstonecraft to conceive of new and more powerful roles for women as well as for men. During the early stages of the "bourgeois revolution," Wollstonecraft desperately tried to include the enfranchisement of women in the new society. That her feminist goals were not accepted in the eighteenth century attests to the great wall of patriarchy she was up against; that she recognized the oppressive architecture of that bourgeois structure so early in its construction demonstrates her extraordinary insight into the problems of her time as well as our own.

From this historical perspective, we can account for the fact that $A$ Vindication is addressed primarily to men by noting that Wollstonecraft composed her treatise in response to those written by the male philosophers of the period. She revered the liberal humanitarian ideals of equal rights for all men propounded by such writers as Edmund Burke and Jean-Jacques Rousseau. Her complaint concerned their failure to consider women in these visions of a new bourgeois society: "Wollstonecraft embraces Rousseau's commitments to independence and freedom and parts with him only in his exclusion of women from this life of independence." 8 Furthermore, Wollstonecraft respected the men themselves, perhaps to an extreme, as supreme philosophers and as embodiments of Reason itself. Her failure to condemn those who were proclaiming women's inferiority can be best understood through the feminist theoretical concept of the "double-bind." Although Wollstonecraft recognized women's oppression and the fact that these respected treatises reinforced sexist attitudes, she nonetheless identified with those philosophers who shared her own humanitarian values. Thus, Wollstonecraft could not alienate herself from the writers she was not only addressing but also striving to emulate.

Wollstonecraft may also have directed her treatise toward these men for the very practical reason that only they had political force, the power to change things. Vlasopolos argues, however, that Wollstonecraft defers too much to her male audience, making unnecessary concessions to avoid alienating the influential and using flattery to mitigate the issues that make men feel least secure ${ }^{9}$ Elizabeth Robins, though writing over a century later as the first President of the Women Writers Suffrage League, provides what was and is still the most appropriate feminist defense against accusations of this sort: "Contrary to the popular impression, to say in print what she thinks is the last thing the woman-novelist or journalist is so rash as to attempt. There even more than elsewhere (unless she is reckless) she must wear the aspect that shall have the best chance of pleasing her brothers. Her publishers are not women."10 
A perhaps more insulting point for women today is not only that Wollstonecraft speaks of women as separate from herself, but that she condescends to them as well, chiding them for their unenlightened conduct. But Wollstonecraft herself must have been confused as to her political role in an age when "true 'writer' signifie[d] assertion while true 'woman' signifie[d] submission." "Writing political tracts in the eighteenth and nineteenth centuries was indeed an exclusively male activity. Thus, Wollstonecraft should not be condemned for failing to overtly recognize her emotional and sexual identity when she was a woman alone in her "masculine" intellectual pursuits. It is more difficult, however, to defend her against accusations of condescension, when she would have been the first to declare that women were not entirely responsible for their behavior. Perhaps the only explanation lies in the frustration she must have experienced as an eighteenth-century feminist striving to achieve a goal for the benefit of all women only to meet resistance from so many women either by choice or by ignorance.

Mary Poovey also chides Wollstonecraft for failing to recognize women as her natural allies in the battle for equal rights. ${ }^{12}$ Wollstonecraft, however, was well aware of the sad state of the eighteenth-century woman's intellectual competence and cannot be faulted for admitting the distressing fact that most women would prove poor comrades in the fight for political equality: "It will also require some time to convince women that they act contrary to their real interest on an enlarged scale, when they cherish or affect weakness under the name of delicacy." ${ }^{13}$ Furthermore, Wollstonecraft understood then what is still true today: the battle is not men versus women but progress versus the status quo. In 1792, it was the philosophers, the men, who were striving to change societal inequalities while the majority of women strove only for the one power they could perceive as attainable, the power to grant or deny their sexual favors. There is a certain irony in the fact that women today are still fighting for that inalienable right.

Poovey aims another reproach at Wollstonecraft for her failure to extend her ideas beyond the limits of bourgeois ideology. ${ }^{14}$ But as Juliet Mitchell points out in Woman's Estate, revolutionary ideas must be articulated first within the structure of the dominant ideology. ${ }^{15}$ Only after the seeds have been planted can revolutionary thinkers begin to explore ideological limitations. Furthermore, Wollstonecraft was wholly in favor of the liberal values expressed by her bourgeois male contemporaries. The problem as she saw it was not the system itself, but the fact that those ideals for financial independence and individual accomplishment did not apply to women. Her goal, there- 
fore, was that of "extending the newly won rights of the middle-class man to the middle-class woman." 16 Hence, it should not be expected that Wollstonecraft would have attempted to develop a theory of women's independence completely outside of the reigning ideology, particularly before the majority of women were fully conscious of their disadvantages within the existing system. A retrospective assessment of her treatise reveals that, instead of giving us a radically revolutionary document, Wollstonecraft "creates an alternative, potentially revolutionary female ideology within a scaffolding of cultural givens" (emphasis mine). ${ }^{17}$ Even today, two centuries after Wollstonecraft planted that seed, it is clear that we have still only begun to approach the "logical, radical extreme" of Wollstonecraft's challenge.

What Wollstonecraft saw as her goal, then, was to create important, contributing roles for women in the new bourgeois society. Although she confines her descriptions to the traditional wife and mother roles, she also sees the powerful potential of these positions in a society where the nuclear family was to become so vital to the economic system. If women were educated and thus afforded the virtuous nature that Reason would insure, they would better educate their children into rational, virtuous adults. Therefore, women would form a powerful moral force behind the new bourgeois society. ${ }^{18}$ However, what Wollstonecraft failed to perceive, according to Zillah Eisenstein, was the increasing division between the home and the economic system with women no longer participating in agriculture and domestic industry beside their husbands. ${ }^{19}$ With the rise of the middle-class, men began working more outside of the home, resulting in the complete exclusion of women from the economic system and their total dependence on their husbands' incomes.

Just as the content of $A$ Vindication may be justified from a feminist historical perspective, the reprimands concerning Wollstonecraft's style merit a feminist linguistic approach. The primary judgment has been that, though Wollstonecraft was capable of logical theorizing and furthermore was addressing herself to men who respected Reason above all else, she often abandons her philosophical style and strays into emotional tirades lamenting the oppressed status of women. ${ }^{20}$ Contemporary feminist theory founded on Lacanian linguistic principles not only explains these diversions but also infers their necessity. In the way a language functions to divide up and filter the infinite realm of reality, much, if not all, of the way we perceive the world is determined, thus precluding other perspectives. Just as feminist critics claim that Western society is inherently patriarchal, so are its languages, meaning that our language can better express the "masculine" 
than the "feminine." Thus, for a woman to speak of the "feminine," she must attempt to work around the language's inherent masculinity: "The challenge facing the woman today is nothing less than to 'reinvent' language . . . to speak not only against, but outside of the specular phallogocentric structure, to establish a discourse the status of which would no longer be defined by the phallacy of masculine meaning."21

Although Wollstonecraft undoubtedly had not developed this theoretical understanding of language, Elissa Guralnick points out that she instinctively sensed that logical discourse and the philosophical rhetoric employed by men could not fully express her ideas: "This argument may be carried further than philosophers are aware of."22 So in order to capture the proper tone for her argument, Wollstonecraft allowed herself a freedom in her philosophical discourse: "Animated by this important object, I shall disdain to cull my phrases or polish my style;-I aim at being useful, and sincerity will render me unaffected; for, wishing rather to persuade by the force of my arguments, than dazzle by the elegance of my language, I shall not waste my time in rounding periods, or in fabricating the turgid bombast of artificial feelings, which, coming from the head, never reach the heart." ${ }^{23}$ Though Guralnick's tone regarding Wollstonecraft's refusal of "the usual requirements of reasoned discourse" suggests a condescending sneer at this idea of freedom, the "sacrifice" of logic is indeed necessary to deconstruct the rules of patriarchal discourse and to allow the expression of a woman's point of view. ${ }^{24}$ This linguistic theory illustrates the feminist idea of marginality; because women are not an integral part of the power structure or its language, they are relegated to marginal roles in Western society. To express that decentered consciousness, women must develop new ways of speaking and writing on the edge of masculine denotations.

Guralnick believes that Wollstonecraft must have adopted her deviant style in A Vindication in order to provide women readers unaccustomed to philosophical discourse some stimulation and encouragement to continue reading. ${ }^{25}$ However, a feminist linguistic perspective would suggest that if Wollstonecraft did intend for women to read her treatise, as several direct addresses indicate, she may have chosen her subversive style in order to speak the marginal argot of women rather than just to adapt to their ignorance. The woman writer's goal, as Luce Irigaray explains it, must be "to try to recover the place of her exploitation by language without allowing herself to be simply reduced to it. It is to resubmit herself . . . to ideas-notably about her-elaborated in and through a masculine logic, but to 'bring 
out' by an effect of playful repetition what was to remain hidden: the recovery of a possible operation of the feminine in language." 26

The most overt evidence of language's inherent patriarchal nature exposes itself in the masculine terms which supposedly refer to all humanity rather than only men. Though Wollstonecraft does not make an issue of these linguistic distinctions, she does bring them to the reader's attention. She points out that the various treatises written by men respecting the liberal rights of "man" actually apply only to the male sex; for example, she firmly censures Rousseau for writing a wholly separate tract on women prescribing their role in the new society as pleasant and pretty companions for men: "Warmly as I admire the genius of that able writer, whose opinions I shall often have occasion to cite, indignation always takes place of admiration, and the rigid frown of insulted virtue effaces the smile of complacency, which his eloquent periods are wont to raise, when I read his voluptuous reveries."27

By commenting on these distinctions, Wollstonecraft demonstrates her awareness of the importance of clarifying ambivalent gender terms in order to promote change. The illusion that philosophers' terms refer to women as well as men has always functioned to pacify women into believing that their interests were being protected. Wollstonecraft also recognizes the ambivalence of the terms "masculine" and "feminine" as they were used in her time (and are still used today). "Masculine" generally referred to such virtues as intelligence, independence, and strength, all those traits that an eighteenthcentury woman would be reproached for demonstrating. "Feminine" virtue, on the other hand, was equated with such traits as delicacy, sensitivity, and obedience, terms Wollstonecraft recognized as barely polite euphemisms for weakness, ignorance, and slavery.

As Wollstonecraft believed that virtue should be founded on Reason and Reason alone, it follows that she would criticize this double standard for male and female virtue as well as the way it is disguised in ambivalent terms. Early in her treatise, she responds to the typical male criticism of "masculine" women: "If it be against the imitation of manly virtues, or, more properly speaking, the attainment of those talents and virtues, the exercise of which ennobles the human character . . . all those who view [women] with a philosophic eye must, I should think, wish with me, that they may every day grow more and more masculine."28

But Wollstonecraft did not admire all of the behaviors commonly considered manly in her time. For instance, she reproaches men for pursuing the sexual favors of women without consideration for the woman's affection or, more importantly at that time, for her "vir- 
tue."29 Consequently, Wollstonecraft advocates a new morality that combines the most reasonable of masculine and feminine virtues: chastity, modesty, and self-control from the female catalogue, and intelligence, strength, and independence from the male's list. ${ }^{30}$ These she calls "human" virtues. By redefining these terms and exposing the double standards inherent in their popular use, Wollstonecraft progressed the emancipation of women in a thoroughly modern way: "The first step in making the 'rights of man' into the 'rights of humanity' and 'masculine' qualities into 'human' ones is to be aware of the persuasive effect of language and to use this effect to clarify rather than confuse." ${ }^{11}$ Feminist linguists today are still battling with the linguistic clarity so necessary for our not yet realized emancipation.

One final topic regarding the criticisms against Wollstonecraft's style pertains to Guralnick's invective that Wollstonecraft strays from the social issue of women's rights into unrelated political issues, such as the evils of monarchy and the standing army. ${ }^{32}$ As Sandra Gilbert reiterates what feminists have pointed out since the earliest days of the women's movement, feminist issues cannot be distinguished from politics: "Not only is the personal the political; the aesthetic is the political, the literary is the political, the rhetorical is the political."33 The fact that Wollstonecraft could not have been familiar with the modern feminist use of the term "patriarchal" in reference to society and language did not prevent her from understanding the extent of change requisite to women's fulfilling significant roles in the economic, political, and social systems. In an age of vast political transition, Wollstonecraft was willing to work within the constructs of bourgeois ideology in the hope that reform would mean a complete restructuring of society, a revolution that would allow women the status claimed for "man."

Considering the vast potential of $A$ Vindication of the Rights of Woman for positive feminist interpretation, it is high time that advanced feminist scholars addressed this pioneering treatise. The issues I have touched on employing a conglomeration of feminist theory all can and should be considered in much more specific detail. It appears to me that no other body of theory can justify and explain so clearly the surprising relevance of $A$ Vindication for today. Even though Wollstonecraft did not have modern theoretical terms at her disposal, there can be little doubt that she understood and expressed many of the basic premises of contemporary social and literary feminist issues: "Wollstonecraft came to understand the social conditions governing the lives of all women and to denounce their institutionalized repression - a social fact that she was the first to grasp in its entirety, and that 
her writings did most to change." 34

Her understanding also came in a time when patriarchy pronounced its domination over every nuance of both personal and institutional society, a time unlike ours when the whispers of patriarchy only remind us that the battle is not yet won. So if the content of her treatise seems sometimes deferential and occasionally irrelevant, we must remember what Elaine Showalter writes about the nineteenth-century artist: "The feminist content of feminist art is typically oblique, displaced, ironic and subversive; one has to read it between the lines, in the missed possibilities of the text." ${ }^{35}$ For instance, there is perhaps only one small moment in A Vindication where Wollstonecraft shyly expresses her true thesis: "A wild wish has just flown from my heart to my head, and I will not stifle it though it may excite a horse-laugh-I do earnestly wish to see the distinction of sex confounded in society." 36 This desire clearly places Wollstonecraft's ideals as firmly in 1987 as in 1792. It is for this wonderful and sad reason that her treatise must be further examined and understood: "Unfortunately, Mary Wollstonecraft's arguments, dated though they may be, have more than historical importance, for her particular battle has not altogether been won."37

\section{NOTES}

1 Virginia Woolf, A Room of One's Own (New York: Harcourt, Brace and World, 1928), 64 .

2 Elissa S. Guralnick, "Rhetorical Strategy in Mary Wollstonecraft's $A$ Vindication of the Rights of Woman," Humanities Association of Canada 30 (1979): 7.

3 Carolyn W. Korsmeyer, "Reason and Morals in the Early Feminist Movement: Mary Wollstonecraft," Women and Philosophy, eds. Carol C. Gould and Marx W. Wartofsky (New York: Capricorn Books), 98.

4 Anca Vlasopolos, "Mary Wollstonecraft's Mask of Reason in A Vindication of of the Rights of Woman," Dalhousie Review 60 (1980): 462-64.

5 Mary Poovey,The Proper Lady and the Woman Writer (Chicago: University of Chicago Press, 1984), 48.

6 Zillah R. Eisenstein, The Radical Future of Liberal Feminism (New York and London:

Longman, Inc., 1981), 102.

7 Guralnick, "Rhetorical Strategy," 2.

8 Eisenstein, 94

9 Vlasopolos, 462-64.

10 Elaine Showalter, "Toward a Feminist Poetics," The New Feminist Criticism, ed. Elaine Showalter (New York: Pantheon Books, 1985), 136.

11 Alicia Ostriker, "The Thieves of Language: Woman Poets and Revisionist Mythmaking" The New Feminist Criticism, ed. Elaine Showalter (New York: Pantheon Books, 1985), 315.

12 Poovey, 79.

13 Mary Wollstonecraft, A Vindication of the Rights of Woman, ed. Carol H. Poston. (New York: W. W. Norton and Co., 1975), 47. 
14 Poovey, 48.

15 Korsmeyer, 108.

16 Eisenstein, 89.

17 Mitzi Myers, "Reform or Ruin: ‘A Revolution in Female Manners'," Studies in Eighteenth-Century Culture 11 (1982): 205.

18 Ibid., 211.

19 Eisenstein, 96-97.

20 Guralnick, "Rhetorical Strategy," 1-2.

21 Shoshana Felman, "Women and Madness: The Critical Phallacy," Diacritics 5 (1975): 10.

22 Elissa S. Guralnick, "Radical Politics in Mary Wollstonecrafts A Vindication of the Rights of Woman," Studies in Burke and His Time 18 (1977): 166.

23 Wollstonecraft, 10.

24 Toril Moi, Sexual/Textual Politics: Feminist Literary Theory (New York and London: Methuen, Inc. 1985), 38-39.

25 Guralnick, "Rhetorical Strategy," 1.

26 Luce Irigaray, Ce sexe qui n'en est pas un (Paris: Editions de Minuit, 1977), 74.

27 Wollstonecraft, 24-25.

28 Ibid., 8.

29 Ibid., 125.

30 Myers, 211.

31 Janet Todd, "The Language of Sex in A Vindication of the Rights of Woman," Mary Wollstonecraft Newsletter 1 (1972): 16.

32 Guralnick, "Radical Politics," 155.

33 Sandra M. Gilbert, "What Do Feminist Critics Want? A Postcard from the Volcano," The New Feminist Criticism, ed. Elaine Showalter (New York: Pantheon Books, 1985), 31 .

34 Ellen Moers, "Vindicating Mary Wollstonecraft," New York Review of Books 19 (February, 1976): 40.

35 Showalter, 138.

36 Wollstonecraft, 57.

37 Korsmeyer, 109. 